\title{
Deskripsi Sikap Siswa Terhadap Pembelajarn IPA di SMPN 1 Muaro Jambi
}

\author{
AZIZA PUTRI NINGSI \\ Pendidikan Fisigss Universitas Jambi \\ Surel : azizap267@gmail.com
}

\begin{abstract}
Abstrak
Penelitian ini dilakukan bertujuan untuk mendeskripsikan sikap siswa terhadap pembelajaran IPA di SMPN 1 Muaro Jambi, bagaimana sikap terhadap penyelidikan IPA di SMPN 1 Muaro Jambi, dan mengetahui apa saja yang menjadi kendala - kendala yang dimiliki oleh siswa maupun guru dalam proses pembentukan sikap saat belajar IPA di SMPN 1 Muaro Jambi, bagaimana cara untuk meningkatkan sikap positif siswa SMP saat diajarkan materi IPA di SMPN 1 Muaro Jambi serta implikasi sosial IPA. Penelitian ini menggunakan pendekatan kelaitatif dengan metode deskriptif. Penelitian ini dilakukan di SMPN 1 Muaro Jambi. Sampel diambil dalam penelitian ini adalah semua siswa SMPN 1 Muaro Jambi. Data penelitian ini menggunakan data kuantitatif. Teknik pengumpulan pada penelitian ini berupa angket. Angket sikap ini dilakukan dengan menggunakan pengukuran skala likert. Penilaian skala Likert adalah sangat setuju (SS), setuju (S), tidak setuju (TS), dan sangat tidak setuju (STS). Dari penelitian ini dapat disimpulka bahwa, penelitian yang dilkukan mengenai sikap siswa terhadap pembelajarn sains di SMPN 1 Muaro Jambi dengan menggunakan indikator implikasi sikap sosial sisiwa terhadap pembelajarn IPA termasuk kedalam kategori baik, siswa lebih dominan memilliki sikap baik dengan persentasenya $60 \%$.
\end{abstract}

Kata Kunci: sikap, pembelajarn IPA, Implikasi sosial IPA

\begin{abstract}
This research was conducted aiming to describe the attitudes of students towards learning science at SMPN 1 Muaro Jambi, how to attitude towards science investigations at SMPN 1 Muaro Jambi, and find out what are the constraints owned by students and teachers in the process of forming attitudes when learning science at SMPN 1 Muaro Jambi, how to improve the positive attitude of junior high school students when taught science material at SMPN 1 Muaro Jambi and the social implications of science. This research uses a relation approach with descriptive method. This research was carried out at SMPN 1 Muaro Jambi. Samples taken in this study were all students of SMPN 1 Muaro Jambi as many as 45 people. This research data uses quantitative data. The collection technique in this study was a questionnaire. This attitude questionnaire was carried out using a Likert scale measurement. Likert scale assessment is strongly agree (SS), agree (S), disagree (TS), and strongly disagree (STS). From this study it can
\end{abstract}


be concluded that, research conducted on students' attitudes towards science learning at SMPN 1 Muaro Jambi by using indicators of the implications of social attitudes of students towards learning science is included in the good category, students are more dominant having good attitudes with a percentage of $60 \%$.

Keywords : attitude, learning science, The social implications of science.

\section{A. PENDAHULUAN}

Pendidikan mambantu dalam proses terjadinya perkembangan manusia. Oleh karena itu untuk meningkatkan kecerdasan sustu bangsa diperlukan pendidikan yang berkualitas dari berbagai ilmu. Education is a process to improve the quality of human life, to get and improve student skills. Sekolah menengah pertama merupakan salah satu lembaga pendidkan yang mempunyai standar lulusan yang akan dicapai yang terdiri dari: sikap, pengetahuan, dan keterampilan. Pada jenjang sekolah menengah pertama terdapat beberapa pelajaran yang berasal dari cabang ilmu alam maupun sosial. Salah satunya adalah mata pelajaran IPA. Pendidkan itu sangat penting karena perkembangan teknologi semakin maju maka pendidikan juga harus mengimbnagai perkembangan teknologi. Oleh karena itu, perlu dilaksanakan pendidikan yang mengembangkan nilai-nilai moral yang baik pada diri siswa.

Pada kegiatan belajar dan pembelajarn terdiri dari pengembangan sikap, pengetahuan, dan keterampilan yang dielaborasi untuk setiap satuan pendidikan termasuk kedalam satndar lulusan sekolah menengah pertama. Salah satu hal yang penting untuk dibahas lebih dalam adalah cakupan sikap. Sikap berasal dari kegiatan "menerima, menjalankan, menghargai, menghayati, dan mengamalkan". Sikap (attitude) adalah pikiran dan perasaan yang mendorong kita bertingkah laku ketika kita menyukai atau tidak menyukai sesuatu $^{1}$. Sikap siswa berperan penting dalam pelatihan sistematis dan ilmiahnya². Sering dijumpai kebenaran kejadian dilapangan, bahwa sikap siswa ketika melnagsungkan membelajaran IPA kurang begitu baik dan kurang begitu disukai disekolah dan siswa sering mengganggap bahwa pelajaranIPA itu bembalajaran yang sangat sulit. Hal ini sesuai dengan pendapat Nurdin \& Lin $^{3}$ mengatakan bahwa mata pelajaran sains sering dianggap sulit, sangat kompleks, rumit dan sulit dipahami oleh siswa. Sikap siswa itu penting, akan tetapi tidak hanya siswa saja yang berperan penting dalam pencapaian sikap positif terhadap pelajaran fisika. Tetapi, guru juga sebagai subjek terlibat dalam proses pendidikan dan pembelajaran. Guru tidak hanya terfokus terhadap pembelajaran fisika saja, tetapi juga harus memahami tentang sikap siswa nya.

Artinya guru juga berperan penting, tentang sikap pada saat proses terjadinya sebuah pembelajaran pada mata pelajaran

\footnotetext{
${ }^{1}$ Hardiyanti, Astalini, and Kurniawan, "SIKAP SISWA TERHADAP MATA PELAJARAN FISIKA DI SMA NEGERI 5 MUARO JAMBI."

2 Trivedi and Sharma, "A Study of Students' Attitude towards Physics Practical at Senior Secondary Level."

${ }^{3}$ Nordin, Lin, and Ling, "Hubungan Mata Pelajaran Sains Dengan Penguasaan Konsep Asas Sains Pelajar Tingkatan Dua."
} 
tertentu, khususnya pada mata pelajaran fisika, dengan adanya guru mengambil peran tentang sikap siswa saat proses pembelajran guru bisa mengetahui sikap siswa terhadap mata pelajaran fisika. Sesuai dengan penjelasan diatas maka peneliti memfokusakan penelitian "sikap siswa terhadap mata pelajaran IPA di SMP Negeri 1 Muaro Jambi".

Ketika proses pembelajaran IPA dickelas dapat dilihat dan diukur sikap siswa terhadap pelajaran IPA. Untuk mengukur sikap siswa di perlukan indikator sikap IPA sebagai berikut yaitu implikasi sosial IPA. Indikator implikasi sosial IPA berkaitan dengan sikap sosial pada diri siswa seperti: belajar, mengajarkan siswa untuk mandiri, bekerjasama dalam hal melakukan percobaan pada proses pembelajaran terhadap mata pelajaran IPA. perasaan bertanggung jawab atas kesulitan dan masalah yang dihadapi oleh orang lain dan kita mempunyai keinginan yang besar untuk membantu dan melakukan sesuatu untuk meringankan dan mengatasi maslah tersebuat itu adalah sikap kepedulian sosial . Kepedulian tidak bisa tumbuh pada diri setiap orang, melainkan membutuhkan proses latihan dan didikan ${ }^{4}$. Kata sikap sering digunakan dalam kehidupan akademi siswa disekolah ${ }^{5}$. Perilaku siswa ketika belajar IPA menunjukkan sikap mereka terhadap mata

\footnotetext{
${ }^{4}$ Aditia, Hamiyati, and Rusilanti, "HUBUNGAN POLA ASUH ORANG TUA DENGAN KEPEDULIAN SOSIAL REMAJA."

${ }^{5}$ Ali et al., "Students' Attitude towards Science and Its Relationship with Achievement Score at Intermediate Level."
}

pelajaran IPA itu sendiri, baik itu sikap positif maupun sikap negative ${ }^{6}$.

Keberhasilan siswa menyerap secara baik materi yang disampaikan guru bisa ditentukan dari siskap siswa selama proses pembelajaran. Secara umum, sikap siswa selama proses pembelajaran berangsung ada yang bersikap positf dan ada yang bersikap negatif. Jadi sikap siswa terhadap proses pembelajaran dapat dllihat ketika mereka memberi tanggapan terhadap pembelajaran tersebut. Siswa yang tekun selama belajar dan memperoleh hasil yang memuaskan merupakan siswa yang mempunyasi sikap positif'. Sikap positif akan membuat siswa berkelakuan baik dan menyelesaikan akademiknya dengan baik. Sikap negative merupakan sikap yang bisa menghambat dalam belajar8. Hal yang paling penting dalam mempelajari tentang sikap terhadap sains adalah bahwa, ketika siswa pertama sekolah mereka tidak langsung menyukai begitu saja pelajaran sains disekolah. sebaian besar keadaan saat ini yang sering terlihat bahwa sikap siswa saat belajaran IPA disekolah kurang begitu baik dan sulit menerima karena mereka menganggap bahwa pembelajaran IPA itu suat mata pelajaran yang sangat sulit dan menakutkan. Selain pengetahua dan psikomotorik, penilaian sikap juga sangat penting karena digunkan sebagai alat ukur untuk melihat minat belajar siswa terhadap fisika melalui sikapnya. Penilaian sikap tidak bisa dinilai secara

\footnotetext{
${ }^{6}$ Hardiyanti, Astalini, and Kurniawan, "SIKAP SISWA TERHADAP MATA PELAJARAN FISIKA DI SMA NEGERI 5 MUARO JAMBI."

${ }^{7}$ Rijal and Bachtiar, "Hubungan Antara Sikap, Kemandirian Belajar, Dan Gaya Belajar Dengan Hasil Belajar Kognitif Siswa."

${ }^{8}$ Guido, "Attitude and Motivation towards Learning Physics."
} 
langsung dan penilaianya itu juga dilakukan secara berkelanjutan pada semua subjek berdasarkan sikap positif dan negatif selama bersekolah di dalam dan di luar pembelajaran, menggunakan lembar observasi atau jurnal.

Penelitian dilakukan pada SMP Negeri 1 Muaro Jambi di kelas IX. Penelitian ini dilakukan bertujuan untuk mendeskripsikan sikap siswa terhadap pembelajaran IPA di SMPN 1 Muaro Jambi, bagaimana sikap terhadap penyelidikan IPA di SMPN 1 Muaro Jambi, dan mengetahui apa saja yang menjadi kendala - kendala yang dimiliki oleh siswa maupun guru dalam proses pembentukan sikap saat belajar IPA di SMPN 1 Muaro Jambi, bagaimana cara untuk meningkatkan sikap positif siswa SMP saat diajarkan materi IPA di SMPN 1 Muaro Jambi serta implikasi sosial IPA.

\section{B. METODE PENELITIAN}

Penelitian ini menggunakan pendekatan kelaitatif dengan metode deskriptif. Penelitian ini dilakukan di SMPN 1 Muaro Jambi. Sampel diambil dalam penelitian ini adalah semua siswa pendidikan SMPN 1 Muaro Jambi. Data penelitian ini menggunakan data kuantitatif. Teknik pengumpulan pada penelitian ini berupa angket. Instrumen penelitian berupa angket yang mengadopsi dari skripsi berupa angket sikap siswa SMP terhadap mata pelajaran IPA. Angket sikap ini dilakukan dengan menggunakan pengukuran skala likert. Penilaian skala Likert adalah sangat setuju (SS), setuju (S), tidak setuju (TS), dan sangat tidak setuju (STS).

Table 1. Kriteria Pensekoran Item Dalan Skala Likert

\begin{tabular}{c|c}
\hline kriteria & skor \\
\hline
\end{tabular}

\begin{tabular}{c|l}
\hline Sangat tidak baik & 1 \\
\hline Tidak baik & 2 \\
\hline baik & 3 \\
\hline Sangat baik & 4 \\
\hline
\end{tabular}

Sumber; (Wilujeng, 2016)

Penelitian ini menggunakan Analisis data angket sikap siswa terhadap mata pelajaran IPA dengan menggunakan statistik deskriptif yaitu menghitung mean, modus, median dan standar deviasi. "Statistik deskriptif adalah statistik yang digunakan untuk menganalisis data dengan cara mendeskripsikan atau menggambarkan data yang telah terkumpul sebagaimana adanya tanpa bermaksud membuat kesimpulan yang berlaku untuk umum atau generalisasi ${ }^{9}$. Mean ditulikan dirumus pada persamaan dibawah ini:

$$
\begin{aligned}
& \bar{X}=\frac{\sum f \cdot X}{\sum f} \\
& \text { Keterangan }: \\
& \bar{X}=\text { mean } \\
& X=\text { data } \\
& f=\text { frekuensi data }
\end{aligned}
$$

Untuk menentukan jarak interval digunakan persamaan dibawan ini :

$i=\frac{\text { skor tertinggi }- \text { skor terendah }}{\text { jumlah kelas interval }}$

Keterangan:

$i=$ jarak interval

Sehingga dapat disusun tabel 2 implikasi sosial siswa pada mebelajaran IPA

\footnotetext{
${ }^{9}$ Sugiyono, Metode Penelitian Pendidikan (Pendekatan Kuantitatif, Kualitatif, Dan R\&D).
} 
Table 2 interval implikasi sosial siswa pada mebelajaran IPA

\begin{tabular}{|l|ll|l|}
\hline No & $\begin{array}{l}\text { Interval rerata } \\
\text { sekor }\end{array}$ & kategori \\
\hline 1 & $53-61$ & $\begin{array}{l}\text { sangat tidak } \\
\text { setuju }\end{array}$ \\
\hline 2 & $62-69$ & tidak setuju \\
\hline 3 & $70-77$ & setuju \\
\hline 4 & $78-85$ & sangat setuju \\
\hline
\end{tabular}

Metode Penelitian bisa meliputi analisa, arsitektur, metode yang dipakai untuk menyelesaikan masalah, implementasi. Bagian ini menjelaskan secara rinci tentang penelitian yang dilakukan.

\section{HASIL DAN PEMBAHASAN}

\section{HASIL}

\section{Implikasi sikap sosial terhadap pembelajaran IPA}

Untuk Indikator implikasi sikap sosial terhadap pembelajarn IPA sangant berkaitan berkaitan dengan sikap sosial yang dimiliki siswa seperti: proses belajar, sikap madiri untuk siswa, bekerjasama dan saling membantu ketika melakukan percobaan saat proses pembelajaran IPA. Berdasarkan sikap soial yang dimiliki siswa tersebut diproleh data hasil analisis statistik deskriptif untuk indikator implikasi sikap sosial siswa terhadap pembelajarn IPA dapat dilihat pada table.

Berdasarkan

penggolongan kategori penyebaran angket implikasi sikap sosial siswa terhadap IPA dengan menggunakan skala interval sebagaimana Tabel 3, diperoleh persentase implikasi sikap sosial siswa terhadap IPA yang telah dilakukan pada siswa SMPN I Kabupaten Muaro Jambi di kelas 9 yang berjumlah 45 orang siswa

Tabel.3 Data hasil Statitik Deskriptif Implikasi Sikap Sosial Siswa terhadap pembelajarn IPA di SMPN 1 Muaro Jambi.

\begin{tabular}{|c|c|c|c|c|c|c|c|c|c|}
\hline \multicolumn{3}{|c|}{ KLASIFIKASI } & Std. & Mean & Modus & Median & Min & Max & $\%$ \\
\hline Rentang & Sikap & Jumlah & \multirow{6}{*}{4.80} & \multirow{6}{*}{71.4} & \multirow{6}{*}{67} & \multirow{6}{*}{71} & \multirow{6}{*}{53} & \multirow{6}{*}{85} & \\
\hline $53-61$ & $\begin{array}{c}\text { sangat tidak } \\
\text { setuju }\end{array}$ & 1 & & & & & & & 2.2 \\
\hline $62-69$ & tidak setuju & 14 & & & & & & & 31.1 \\
\hline $70-77$ & setuju & 27 & & & & & & & 60 \\
\hline $78-85$ & $\begin{array}{l}\text { sangat } \\
\text { setuju }\end{array}$ & 3 & & & & & & & 6.7 \\
\hline total & & 45 & & & & & & & $100 \%$ \\
\hline
\end{tabular}




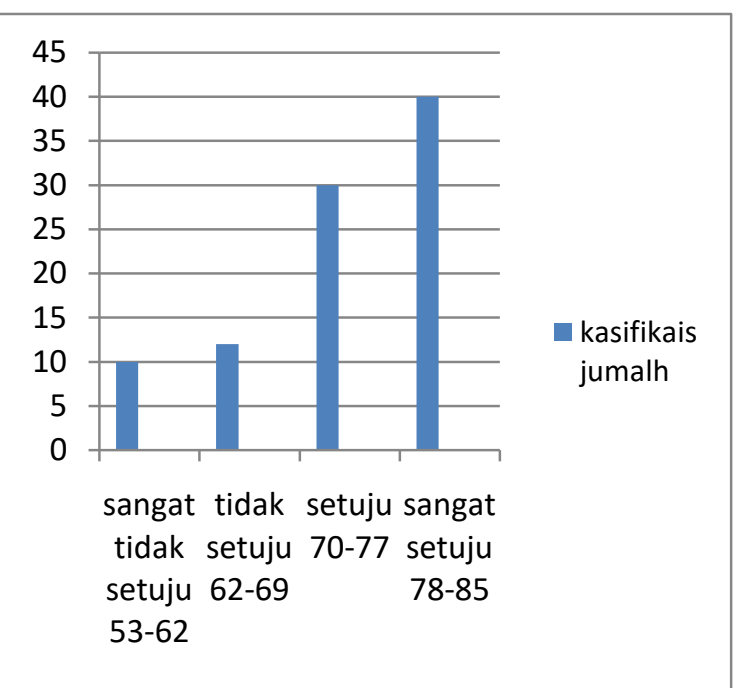

Gambar 1. Grafik implikasi sikap sosial siswa terhadap IPA yang telah dilakukan pada siswa SMPN I Kabupaten Muaro Jambi

Skala sikap digunakan untuk melihat sikap siswa terhadap objek tertentu, hasil kategori sikap antara lain; menolak (negatif), mendukung (positif) (Nana dkk, 2012). Hasil data pada penelitian ini didapatkan dari penyebaran angket implikasi sikap sosial siswa terhadap IPA yang telah dilakukan pada siswa SMPN I Kabupaten Muaro Jambi di kelas 9 yang berjumlah 45 orang siswa. Hasil data angket sikap yang ditampilkan pada analisis data di bawah ini terdiri 2 bagian penilaian. Pertama adalah penilaian berdasarkan interval yang memliki kategori sikap sebagai berikut: sangat baik, baik, tidak baik, sangat tidak baik. Penilaian kategori sikap ini berdasarkan frekuensi dan persentase seluruh siswa yang memilih setiap kategori sikap.

Berdasarkan table 3 implikasi sikap sosial siswa mata pelajaran IPA di SMPN 1 Muaro Jambi diketahui bahwa siswa lebih dominan memilliki sikap baik dengan nilai pada rentang 70-77 sebanyak 27 siswa dan persentasenya 60\%. Untuk siswa yang memiliki skala sangat baik dengan nilai pada rentang 78-85 sebanyak 3 siswa dan persentasenya $6.7 \%$. untuk siswa yang memiliki sikap tidak baik sebanyak 14 siswa dengan nilai pada rentang 62-69 dan persentasenya $31.1 \%$. Sedangkan siswa yang memiliki sikap sangat tidak baik yaitu dengan nilai pada rentang 53-61 sebanyak 1 orang siswa dan persentasenya $2.2 \%$. Jadi dari hasil datadata tersebut kita dapat disimpulkan bahwa siswa lebih cenderung memilki sikap baik pada indikator implikasi sikap sosial siswa pada pelajaran IPA karena siswa menganggap pembelajaran IPA membuat kehidupan menjadi lebih baik dan sejalan dengan kehidupan sosial yaitu saling berinterkasi langsung dengan alam, Sedangkan untuk siswa yang cenderung memiliki sikap kurang baik dan sikap tidak baik karena siswa menganggap mata pelajaran IPA menakutakan dan sulit untuk dipahami.

\section{PEMBAHASAN}

indikator implikasi sikap sosial siswa terhadap pembelajaran IPA itu sangat penting karena dengan adanya indikator tersebut bisa menanamkan pemikiran kepada siswa agar tidak semata-mata menganggap mata pelajaran IPA menakutkan dan sulit. Melainkan siswa harus menganggap bahwa pembelajarn IPA itu merupakan satu mata pelajaran yang memiliki cakupan luas dialam dan berinterkasi langsung dengan kehidupan di sekitar kita. Indikator implikasi sikap sosial merupakan bagian dari sikap siswa terhadap pembelajaran IPA yang terdiri dari berbagai macam kategori. Untuk kategori siswa yang memiliki sikap baik berjumlah 27 siswa dengan persentase $60 \%$ merupakan kategori lebih dominan. Sedangkan siswa 
yang memiliki sikap tidak baik berjumlah 14 siswa dengan persentase 31.1\%. Dari penjelasan tersebut terlihat bahwa pada Kategori sikap baik lebih dominan dikarenakan peserta didik dan guru selalu aktif berinterkasi antara yang stau dengan yang lain saat guru menyampikan materi pembelajarn pada peserta didik. Dengan adanya interkasi dan saling keterkaitan antara guru dan siswa, serta interaksi antar siswa yang satu dengan siswa yang lainya, maka terciptalah kegiatan sosial yang baik saat pelajaran IPA. Interkasi sosial yang baik antara guru dan siswa dapat meningkatkan hasil belajar siswa. Menurut (Arnita dkk, 2016), Untik menciptakan dampak positif saat menilai hasil belajar siswa dapat dilakukan dengan cara memberi kenyamanan siswa dengan Interaksi yang baik yang terjalin baik antara guru dan siswa.

\section{PENUTUP}

\section{KESIMPULAN}

Dari penelitian ini dapat disimpulka bahwa, penelitian yang dilkukan mengenai sikap siswa terhadap pembelajarn sains di SMPN 1 Muaro Jambi dengan menggunakan indikator implikasi sikap sosial sisiwa terhadap pembelajarn IPA termasuk kedalam kategori baik. Dari penelitian ini, diharapkan dapat memberikan kontribusi bahwa sikap siswa SMPN 1 Muaro Jambi dapat meningkatkan motivasi belajar siswa sehingga prestasi belajar siswa menjadi lebih tinggi dan juga diharapkan bisa memotivasi sekolah yang ada di sekitar utuk menjadi lebih baik. Melalui partisipasi siswa, guru bisa kmeningkatkan pengajaran sains dan proses pembelajaran di kelas. Menurut (Kurniawan dkk, 2018), hasil belajar sains siswa lebih optimal apabila siswa itu menerima dan bersikap positif terhadap pembelajarn sains/IPA.

\section{SARAN}

diharapkan kepada guru dan pihak sekolah agar selaluh memperhatikan siskap siswa saat proses pembelajaran, dengan demikian guru bisa memperbaikai sikap siswa terhadap pembelajaran tersebut.

\section{E. DAFTAR PUSTAKA}

Aditia, Hana Rizkia, Hamiyati Hamiyati, and Rusilanti Rusilanti. "HUBUNGAN POLA ASUH ORANG TUA DENGAN KEPEDULIAN SOSIAL REMAJA." JKKP (Jurnal Kesejahteraan Keluarga Dan Pendidikan) 3, no. 2 (October 10, 2016): 89-93.

https://doi.org/10.21009/jkkp.032.0 8.

Ali, Muhammad Shabbir, Asif Iqbal, Mahr Muhammad, and Saeed Akhtar. 'Students' Attitude towards Science and Its Relationship with Achievement Score at Intermediate Level." Journal of Elementary Education. Vol. 25, n.d.

Guido, Ryan Manuel D. "Attitude and Motivation towards Learning Physics." International Journal of Engineering Research \& Technology (IJERT) 2 (May 6, 2018): 2278-0181. http://arxiv.org/abs/1805.02293.

Hardiyanti, Kiki, Astalini Astalini, and Dwi Agus Kurniawan. "SIKAP SISWA TERHADAP MATA PELAJARAN FISIKA DI SMA NEGERI 5 MUARO JAMBI." EduFisika 3, no. 02 (December 15, 2018): 1-12. https://doi.org/10.22437/edufisika.v 3i02.4522.

Nordin, Aziz, \& Lin, and Hui Ling.

"Hubungan Mata Pelajaran Sains Dengan Penguasaan Konsep Asas Sains Pelajar Tingkatan Dua." Journal of Science \& Mathematics Educational 
2 (2011): 2231-7368.

https://core.ac.uk/reader/11788680.

Rijal, Syamsu, and Suhaedir Bachtiar.

"Hubungan Antara Sikap, Kemandirian Belajar, Dan Gaya Belajar Dengan Hasil Belajar Kognitif Siswa." Bioedukatika 3, no. 2 (2015): 15-20.

http://bioedukatika.uad.ac.id/wpcontent/uploads/2015/12/3.-JurnalBioedukatika-Sysamsi-rijal-15-20.pdf.

Sugiyono. Metode Penelitian Pendidikan (Pendekatan Kuantitatif, Kualitatif, Dan $R \& D)$. Bandung: Alfabeta, 2013.

Trivedi, Rakhee, and M P Sharma. "A Study of Students' Attitude towards Physics Practical at Senior Secondary Level." International Journal of Scientific and Research Publications 3, no. 8 (2013). www.ijsrp.org. 